University of Nebraska - Lincoln

DigitalCommons@University of Nebraska - Lincoln

Faculty Publications from Nebraska Center for Research on Children, Youth, Families, and Schools

2009

\section{Postconventional Morality}

Maria Rosario de Guzman

University of Nebraska-Lincoln, mguzman2@unl.edu
Children, Youth, Families \& Schools, Nebraska Center for Research on

Follow this and additional works at: https://digitalcommons.unl.edu/cyfsfacpub

Part of the Pre-Elementary, Early Childhood, Kindergarten Teacher Education Commons

de Guzman, Maria Rosario, "Postconventional Morality" (2009). Faculty Publications from Nebraska Center for Research on Children, Youth, Families, and Schools. 9.

https://digitalcommons.unl.edu/cyfsfacpub/9

This Article is brought to you for free and open access by the Children, Youth, Families \& Schools, Nebraska Center for Research on at DigitalCommons@University of Nebraska - Lincoln. It has been accepted for inclusion in Faculty Publications from Nebraska Center for Research on Children, Youth, Families, and Schools by an authorized administrator of DigitalCommons@University of Nebraska - Lincoln. 


\section{Maria Rosario T. de Guzman}

Department of Child, Youth, \& Family Studies

University of Nebraska-Lincoln

Published in David Matsumoto, ed., Cambridge dictionary of psychology (Cambridge, MA: Cambridge University Press, 2009), p 393. 


\section{postconventional morality}

$n$. In Kohlberg's theory of moral development, this is the third and highest level of reasoning, characterized by a reliance on autonomous moral principles. Two stages compose this level of moral reasoning. In stage 5, social contract orientation, individuals base their moral judgments on the degree to which actions promote commonly agreed upon laws and rules. Unlike in earlier stages, rules are not obeyed simply to avoid punishment (stage 1) or to obey authority for authority's sake blindly (stage 4), but because they represent social contracts agreed upon by the larger society and are based on principles that benefit the greater majority. Rules are seen as flexible, depending on their continued utility. In stage 6 , ethical principle orientation, moral reasoning is based on selfchosen ethical principles which are abstract, universal, and context free. These principles are maintained because they are ends in themselves, rather than means to an end. It has been argued that the postconventional level of morality can only be found in complex urban societies (both Western and nonWestern).

- MRTG 